\title{
Superparamagnetic Ironoxide Nanoparticles via Ligand Exchange Reactions: Organic 1,2-Diols as Versatile Building Blocks for Surface Engineering
}

\author{
Wolfgang H. Binder, Harald Weinstabl, and Robert Sachsenhofer \\ Faculty of Natural Sciences II (Chemistry and Physics), Institute of Chemistry/Macromolecular Chemistry, \\ Martin-Luther University (MLU)-Halle-Wittenberg, Heinrich-Damerowstr. 4/TGZ III, 06120 Halle (Saale), Germany
}

Correspondence should be addressed to Wolfgang H. Binder, wolfgang.binder@chemie.uni-halle.de

Received 28 February 2008; Accepted 9 May 2008

Recommended by S. Liao

A method for the preparation of ligand-covered superparamagnetic iron oxide nanoparticles via exchange reactions is described. 1,2-diol-ligands are used to provide a stable binding of the terminally modified organic ligands onto the surface of $\gamma$-Fe $\mathrm{O}_{2}$ nanoparticles $(r \sim 4 \mathrm{~nm})$. The 1,2-diol-ligands are equipped with variable terminal functional groups (i.e., hydrogen bonding moieties, azido- bromo-, fluorescent moieties) and can be easily prepared via osmium tetroxide-catalyzed 1,2-dihydroxylation reactions of the corresponding terminal alkenes. Starting from octylamine-covered $\gamma-\mathrm{Fe}_{2} \mathrm{O}_{3}$-nanoparticles, ligand exchange was effected at $50^{\circ} \mathrm{C}$ over $24-48$ hours, whereupon complete ligand exchange is taking place as proven by thermogravimetric (TGA)and IR-spectroscopic measurements. A detailed kinetic analysis of the ligand exchange reaction was performed via TGA analysis, demonstrating a complete ligand exchange after 24 hours. The method offers a simple approach for the generation of various $\gamma$ - $\mathrm{Fe}_{2} \mathrm{O}_{3}$-nanoparticles with functional organic shells in a one-step procedure.

Copyright (c) 2008 Wolfgang H. Binder et al. This is an open access article distributed under the Creative Commons Attribution License, which permits unrestricted use, distribution, and reproduction in any medium, provided the original work is properly cited.

\section{INTRODUCTION}

Magnetic iron oxide nanoparticles have gained increased interest during the past decade, mostly due to their superparamagnetic property present at small particle sizes $[1$, 2]. Thus below a critical size of $\sim 40 \mathrm{~nm}$, the formation of Weiss domains is no longer possible, leading to the formation of singular magnetic domains and thus the physicochemical phenomenon of superparamagnetism. With the advent of this discovery, numerous exploitations have gained advantage of this effect, mostly due to the inability of superparamagnetic nanoparticles to self-aggregate, thus preventing large agglomerate formation. Applications such as drug and gene delivery $[3,4]$, magnetic resonance imaging [5], hyperthermia [6-8], and magnetofection [9-11] have demonstrated the wide applicability of superparamagnetic nanoparticles in vivo and in vitro.

A critical issue for the use of these nanoparticles is represented by engineering the surface of the nanoparticles with organic ligands, thus allowing the incorporation, selec- tive recognition, or specific guidance of such nanoparticles. Based on various approaches, a large number of different organic ligands have been described, including ligands such as polymeric $[12-14]$, peptidic $[15,16]$, protein ligands [1719], or small organic molecules such as fluorescent dyes $[20,21]$, biotine [22], drugs, and others [23, 24]. Critical for the achievement of a sufficient stability between the surface of the nanoparticles and the corresponding ligands is the choice of either a multivalent adsorption site (usually present between polymeric ligands and the surface of the iron-oxide nanoparticles) or the use of a specific functional group, binding tightly to the surface of the iron oxide nanoparticles. Inorganic shells, such as silicon dioxide [25-29] have been used extensively as an intermediate shell between the ironoxide core and the organic ligands, usually binding via terminal aminoligands incorporated on the surface of the silica shell. When purely organic ligands are directly bound to the surface of the iron oxide nanoparticles, carboxylate ligands [30, 31], sulfonates and thiols [32, 33], phosphates and phosphonates [34], as well as aminoligands [35] are 
used. Recently, Boal et al. [36] have introduced the use of 1,3-diol-ligands for achieving a tight binding of various organic ligands on the iron oxide nanoparticle surface. 1,3diols were found superior as ligands in comparison to pure alcoholic substrates, since binding constants of the latter are not sufficient in order to achieve sufficient binding stability.

In the present publication, we report on the use of 1,2-diol-ligands instead of 1,3-diol-ligands for the binding of various ligands to the surface of superparamagnetic iron oxide nanoparticles (see Figure 1) via ligand exchange reactions. In contrast to 1,3-diols, 1,2-diols can be generated easily from the corresponding terminal alkenes via an osmium tetraoxide mediated dihydroxylation reaction, thus achieving a broad spectrum of substrates at the end of the ligand. The binding of various ligands with fluorescent and supramolecular properties onto the surface of the iron oxide nanoparticles together with the kinetic progress of the ligand exchange reaction is reported, allowing a simple and efficient functionalization of the iron oxide nanoparticles.

\section{EXPERIMENTAL SECTION}

\subsection{General procedures}

Sodium azide $\left(\mathrm{NaN}_{3}\right)$ was from Acros and $\mathrm{Cu}(\mathrm{I}) \mathrm{Br}(99 \%)$ from Fluka. All chemicals were used directly without any further purification. Tetrahydrofuran (THF), diethylether, and toluene were dried by distillation over sodium and benzophenone, dimethylformamide (DMF) over $\mathrm{CaH}_{2}$, and methanol over magnesium. NMR spectra were obtained with a $200 \mathrm{MHz}$ Bruker AC200 spectrometer and a $400 \mathrm{MHz}$ Bruker Advance DRX $400 \mathrm{MHz}$. Chloroform $\left(\mathrm{CDCl}_{3}\right)$ and dimethylsulfoxide (DMSO- $\mathrm{d}_{6}$ ) were used as solvents, tetramethylsilane (TMS) as internal standard. Photoluminescence spectra were recorded on a Perkin-Elmer luminescent spectrometer LS 50 B system equipped with a pulsed Xe discharge lamp as the excitation light source $(400 \mathrm{~nm})$ and a photomultiplier detector. UV-VIS spectroscopy was performed on a Hitachi U-2001 spectrophotometer using UV Solutions (Version 1.2, Build 122, Hitachi instruments) for data interpretation. TEM measurements were achieved on a Phillips EM300 microscope, using an accelerating voltage of $100 \mathrm{kV}$. A droplet of the nanoparticle solution $(0.1-1 \mathrm{mg} / \mathrm{ml})$ was applied on standard TEM-grids (300 mesh copper carbon only $(50 \mathrm{ct}))$ purchased from Electron Microscopy Sciences and dried at ambient conditions. DLS measurements were done on an ALV/CGS-3 compact goniometer using the ALV5000/E correlator software.

\subsection{Synthesis}

\subsubsection{Preparation of the 1,2-diol-ligands $\mathbf{1 a - 1 f}$ by osmium-tetroxide catalyzed dihydroxylation reaction of terminal olefines $\mathbf{2 a - 2 f}$}

The corresponding olefin was suspended in the denoted amount of Ar-bubbled solvent. NMO $\cdot \mathrm{H}_{2} \mathrm{O}(\mathrm{N}$-methylmorpholine-N-oxide monohydrate) was added in the specified amount. The solution was stirred at room temperature until all reagents were dissolved. During agitation, the solution was bubbled with argon. Now catalytic amounts (one granule) of $\mathrm{OsO}_{4}$ were added in Ar counterflow. The solution turned immediately yellow after the addition. The reaction mixture was stirred at room temperature until TLC indicates full conversion, which in all cases occurred after 1 hour. Since $\mathrm{OsO}_{4}$ is a very strong oxidizing agent it has to be decomposed before workup. Therefore $50 \mathrm{~mL}$ of an aqueous $10 \mathrm{w} \% \mathrm{NaHSO}_{3}$ solution were added. The reaction mixture turned violet and a precipitate occurred, which was filtered. Phases were transferred into a separation funnel and separated. The organic layer was washed twice with water and dried with brine and $\mathrm{Na}_{2} \mathrm{SO}_{4}$. Solvents were removed under reduced pressure.

\subsubsection{Data for the ligands $\mathbf{1 a - 1 f}$}

\section{5-(10,11-dihydroxyundecyl)-5-ethylpyrimidine- 2,4,6-trione 1a}

The alkene $2 \mathrm{a}(3 \mathrm{~g}, 9.73 \mathrm{mmol})$, $\mathrm{NMO} \cdot \mathrm{H}_{2} \mathrm{O}(3 \mathrm{~g}, 21.90$ $\mathrm{mmol}$ ), and $\mathrm{OsO}_{4}$ were suspended in $50 \mathrm{~mL}$ dichloromethane and treated according to the general dihydroxylation procedure described above. The crude product was purified by silica gel chromatography $(\mathrm{EE} /$ hexane $=3 / 1)$ yielding in 1a as a colorless oil (3g, 90\%). $R_{f}=0.48$ $(\mathrm{EE} /$ hexane $=3 / 1) .{ }^{1} \mathrm{H}-\mathrm{NMR}\left(200 \mathrm{MHz}, \mathrm{DMSO}-\mathrm{d}_{6}\right) \delta(\mathrm{ppm})$ $=11.57(\mathrm{~s}, 2 \mathrm{H}), 4.40(\mathrm{~m}, 2 \mathrm{H}), 3.26(\mathrm{~m}, 2 \mathrm{H}), 1.83(\mathrm{t}$, $4 \mathrm{H}) 1.39-1.23(\mathrm{~m}, 16 \mathrm{H}), 0.77(\mathrm{t}, 3 \mathrm{H}) .{ }^{13} \mathrm{C}-\mathrm{NMR}(50 \mathrm{MHz}$, DMSO- $\left.\mathrm{d}_{6}\right) \delta(\mathrm{ppm})=174.12,150.86,72.06,66.97,56.71$, $38.91,34.38,32.66,30.26,30.02$, 29.84, 29.59, 26.16, 25.46 .

\subsubsection{1-Azidoundecane-1,2-diol $\mathbf{1 b}$}

Starting from the alkene $\mathbf{2 b}(520 \mathrm{mg}, 2.66 \mathrm{mmol})$, NMO $\mathrm{H}_{2} \mathrm{O}(730 \mathrm{mg}, 5.32 \mathrm{mmol})$ and $\mathrm{OsO}_{4}$ according to the general dihydroxylation procedure described above, 1b (586 mg, $96 \%$ ) was obtained as colorless oil after purification by silica gel chromatography $(\mathrm{EE} /$ hexane $=1 / 1) . R_{f}=0.30$ $(\mathrm{EE} /$ hexane $=1 / 1)$.

${ }^{1} \mathrm{H}-\mathrm{NMR}\left(200 \mathrm{MHz}, \mathrm{CDCl}_{3}\right) \delta(\mathrm{ppm})=4.80($ broad $\mathrm{s}$, $2 \mathrm{H}), 3.57(\mathrm{~d}, 2 \mathrm{H}), 3.38(\mathrm{~m}, 1 \mathrm{H}), 3.24(\mathrm{t}, 2 \mathrm{H}), 1.59(\mathrm{~m}, 2 \mathrm{H})$, $1.29(\mathrm{~m}, 14 \mathrm{H}) .{ }^{13} \mathrm{C}-\mathrm{NMR}\left(50 \mathrm{MHz}, \mathrm{CDCl}_{3}\right) \delta(\mathrm{ppm})=72.22$, $66.60,51.32,32.93,29.53,29.32,29.02,28.69,26.57,25.50$.

\subsubsection{1-Bromoundecane-1,2-diol 1c}

11-Bromoundec-1-ene 2c (1 g, $4.29 \mathrm{mmol}), \mathrm{NMO} \cdot \mathrm{H}_{2} \mathrm{O}$ $(1.3 \mathrm{~g}, 9.43 \mathrm{mmol})$, and $\mathrm{OsO}_{4}$ were dissolved in $20 \mathrm{~mL}$ dichloromethane and treated along the general dihydroxylation procedure described above, yielding product $1 \mathrm{c}$ as a white solid $(1.12 \mathrm{~g}, 98 \%) . R_{f}=0.44(\mathrm{EE} / \mathrm{hexane}=3 / 1) .{ }^{1} \mathrm{H}$ NMR $\left(200 \mathrm{MHz}, \mathrm{CDCl}_{3}\right) \delta(\mathrm{ppm})=4.80($ broad s, $2 \mathrm{H}), 3.57$ $(\mathrm{d}, 2 \mathrm{H}), 3.38(\mathrm{~m}, 1 \mathrm{H}), 3.40(\mathrm{t}, 2 \mathrm{H}), 1.81(\mathrm{~m}, 2 \mathrm{H}), 1.41(\mathrm{~m}$, $2 \mathrm{H}), 1.29(\mathrm{~m}, 12 \mathrm{H}) .{ }^{13} \mathrm{C}-\mathrm{NMR}\left(50 \mathrm{MHz}, \mathrm{CDCl}_{3}\right) \delta(\mathrm{ppm})=$ $72.22,66.60,33.97,33.02,32.72,29.30,28.66,28.05,25.51$. 


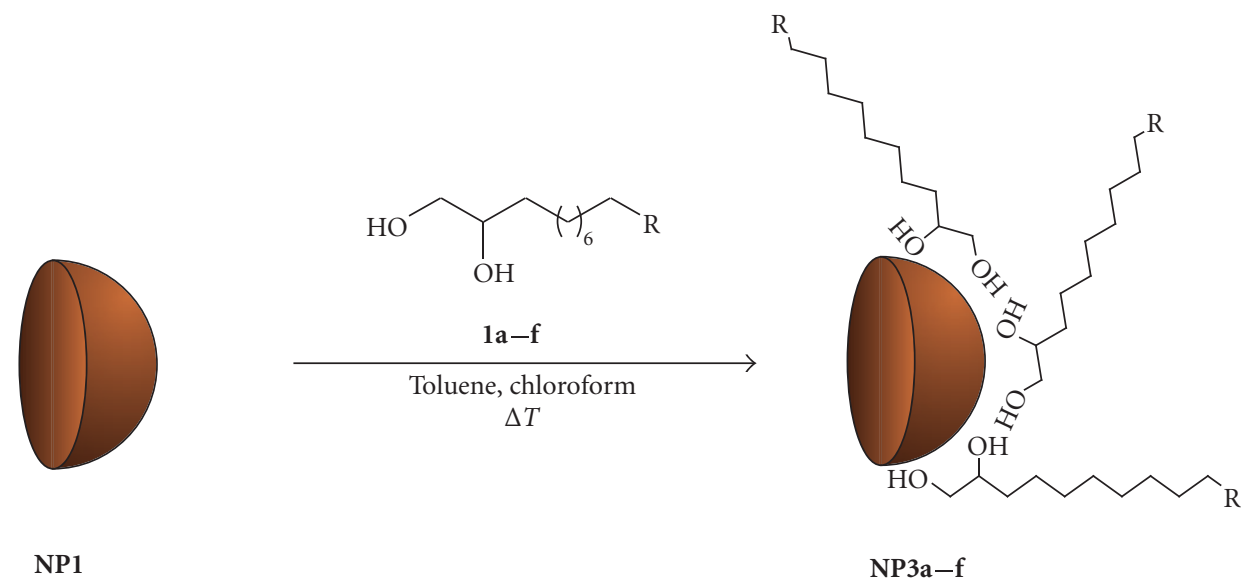

(octylamine covered)

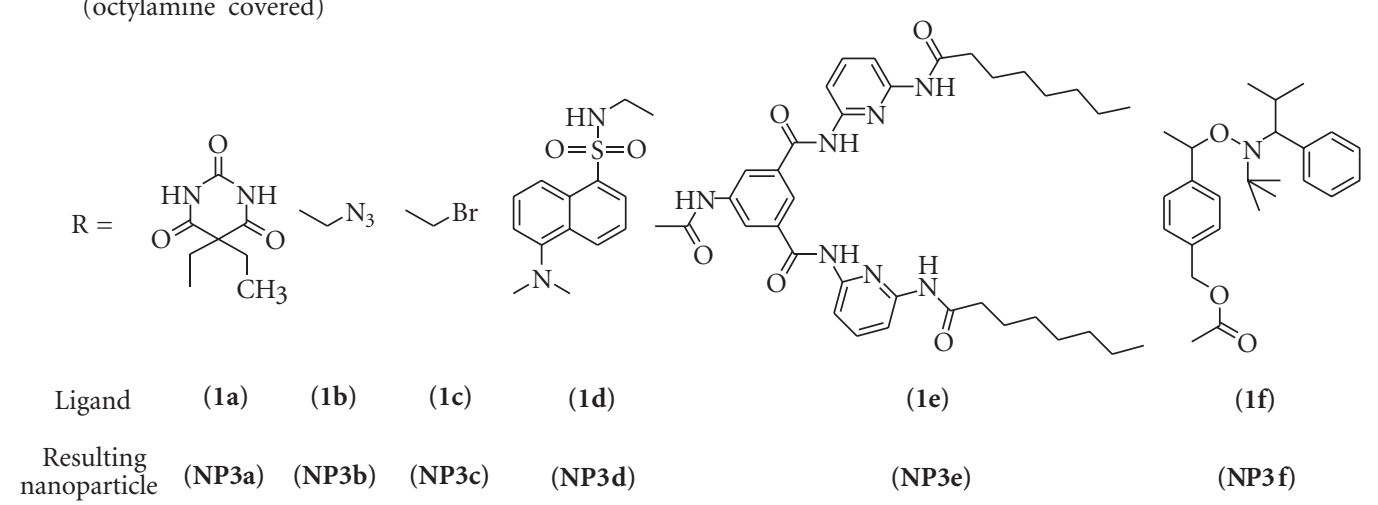

FIgURE 1: Modification of octylamine-covered $\mathrm{Fe}_{2} \mathrm{O}_{3}$-nanoparticles NP1 $(r=\sim 4 \mathrm{~nm})$ via ligand exchange reactions using terminally substituted 1,2-diol-ligands.

\subsubsection{5-(dimethylamino)- $\mathrm{N}$-(undec-10-enyl)naphthalene- 1-sulfonamide 1d}

Alkene 2d (400 mg, $1 \mathrm{mmol}), \mathrm{NMO} \cdot \mathrm{H}_{2} \mathrm{O}(275 \mathrm{mg}, 2 \mathrm{mmol})$, and $\mathrm{OsO}_{4}$ were reacted in $20 \mathrm{~mL}$ dichloromethane and treated along the general dihydroxylation procedure described above. The crude product was purified by silica gel chromatography (EE/hexane $=3 / 1$ ) yielding in $\mathbf{1 d}$ as yellow green oil $(410 \mathrm{mg}, 94 \%) . R_{f}=0.23(\mathrm{EE} / \mathrm{hexane}=$ 3/1). ${ }^{1} \mathrm{H}-\mathrm{NMR}\left(200 \mathrm{MHz}, \mathrm{CDCl}_{3}\right) \delta(\mathrm{ppm})=8.54(\mathrm{~d}, 1 \mathrm{H})$, $8.27(\mathrm{~m}, 2 \mathrm{H}), 7.55(\mathrm{~m}, 2 \mathrm{H}), 7.19(\mathrm{~d}, 1 \mathrm{H}), 4.71$ (broad s, $1 \mathrm{H})$, $3.63(\mathrm{~d}, 2 \mathrm{H}), 3.42(\mathrm{~m}, 1 \mathrm{H}), 2.89(\mathrm{~s}, 6 \mathrm{H}), 2.04$ (broad s, $2 \mathrm{H})$, $1.38-1.10(\mathrm{~m}, 18 \mathrm{H}) .{ }^{13} \mathrm{C}-\mathrm{NMR}\left(50 \mathrm{MHz}, \mathrm{CDCl}_{3}\right) \delta(\mathrm{ppm})$ $=134.92,130.11,129.70,129.64,129.55,128.20,123.56$, $115.41,72.26,66.68,45.56,43.32,33.74,29.50,29.26,29.00$, $28.91,28.84,26.37$.

\subsubsection{5-(10,11-dihydroxyundecanamido)- $N^{1}, N^{3}$-bis(6- octanamidopyridin-2-yl)isophthalamide 1 e}

The alkene $2 \mathrm{e}(500 \mathrm{mg}, 0.64 \mathrm{mmol}), \mathrm{NMO} \cdot \mathrm{H}_{2} \mathrm{O}(176 \mathrm{mg}$, $1.28 \mathrm{mmol}$ ), and $\mathrm{OsO}_{4}$ were dissolved in $15 \mathrm{~mL}$ dichloromethane and treated along the general dihydroxylation procedure described above. No further purification was necessary. Product 1e was obtained as white solid $(512 \mathrm{mg}$, $98 \%) . R_{f}=0.31(\mathrm{EE} /$ hexane $=4 / 1) .{ }^{1} \mathrm{H}-\mathrm{NMR}(200 \mathrm{MHz}$,
$\left.\mathrm{CDCl}_{3}\right) \delta(\mathrm{ppm})=9.34(\mathrm{~s}, 1 \mathrm{H}), 8.93-7.37(\mathrm{~m}, 9 \mathrm{H}), 3.63$ $(\mathrm{d}, 2 \mathrm{H}), 3.42(\mathrm{~m}, 1 \mathrm{H}), 3.41(\mathrm{t}, 2 \mathrm{H}), 2.50-2.35(\mathrm{~m}, 6 \mathrm{H})$, $2.00(\mathrm{~m}, 2 \mathrm{H}), 1.73(\mathrm{~m}, 2 \mathrm{H}), 1.62(\mathrm{~m}, 4 \mathrm{H}), 1.27(\mathrm{~m}$, $24 \mathrm{H}), 0.87(\mathrm{t}, 6 \mathrm{H}) .{ }^{13} \mathrm{C}-\mathrm{NMR}\left(50 \mathrm{MHz}, \mathrm{CDCl}_{3}\right) \delta(\mathrm{ppm})$ $=173.03,164.72,156.23,149.04,141.07,137.63,134.57$, $120.65,120.53,105.83,75.44,70.5836 .11,33.86,31.83$, $29.69,29.58,28.94,28.65,28.63,25.64,22.73,14.11$.

\subsubsection{4-(1-(tert-butyl(2-methyl-1- phenylpropyl)aminooxy)ethyl)benzyl 10,11-dihydroxyundecanoate $1 \mathbf{f}$}

The alkene 2f [37] (450 mg, $0.86 \mathrm{mmol}$ ), $\mathrm{NMO} \cdot \mathrm{H}_{2} \mathrm{O}$ $(237 \mathrm{mg}, 1.73 \mathrm{mmol})$, and $\mathrm{OsO}_{4}$ were dissolved in $20 \mathrm{~mL}$ dichloromethane and treated according to the general dihydroxylation procedure described above. No further purification was necessary. Product 1f was obtained as colorless oil (461 mg, 96\%). $R_{f}=0.46\left(\mathrm{CHCl}_{3} / \mathrm{MeOH}=20 / 1\right) .{ }^{1} \mathrm{H}-$ $\operatorname{NMR}\left(200 \mathrm{MHz}, \mathrm{CDCl}_{3}\right) \delta(\mathrm{ppm})=7.42-7.15(\mathrm{~m}, 18 \mathrm{H})$, $4.12-3.16(\mathrm{~m}, 10), 2.33(\mathrm{t}, \mathrm{J}=7.5 \mathrm{~Hz}, 4 \mathrm{H}), 1.63-1.32(\mathrm{~m}$, $15 \mathrm{H}), 2.00(\mathrm{q}, 4 \mathrm{H}), 1.55(\mathrm{~m}, 11 \mathrm{H}), 1.25(\mathrm{~s}, 16 \mathrm{H}), 1.05(\mathrm{~s}$, $9 \mathrm{H}), 0.96\left(\mathrm{~d},{ }^{3} \mathrm{~J}=6.2 \mathrm{~Hz}, 3 \mathrm{H}\right), 0.77(\mathrm{~s}, 9 \mathrm{H}), 0.55\left(\mathrm{~d},{ }^{3} \mathrm{~J}=\right.$ $6.4 \mathrm{~Hz}, 3 \mathrm{H}), 0.22\left(\mathrm{~d},{ }^{3} \mathrm{~J}=6.4 \mathrm{~Hz}, 3 \mathrm{H}\right) .{ }^{13} \mathrm{C}-\mathrm{NMR}(50 \mathrm{MHz}$, $\left.\mathrm{CDCl}_{3}\right) \delta(\mathrm{ppm})=169.08,146.03,145.31,142.22,142.11$, $140.04,136.44,135.69,130,82,127.56,126.73,125.65$, $121.37,121.09,119.13,109.52,108.77,82.59,81.68,71.53$, 
$66.48,36.89,35.08,31.46,31.17,28.27,27.86,24.91,24.22$, $22.58,22.08,21.59,20.55,20.46$.

\subsubsection{Preparation of superparamagnetic iron-oxide nanoparticles NP1}

Preparation of octylamine-covered nanoparticles was accomplished according to literature $[35,36]$. In brief, a solution of iron cupferron complex $(780 \mathrm{mg}, 1.5 \mathrm{mmol})$ in octylamine $(3.90 \mathrm{~g}, 27.22 \mathrm{mmol})$ was alternately evacuated to $10 \mathrm{mbar}$ and aerated with $\mathrm{Ar}$ at $60^{\circ} \mathrm{C}$. Trioctylamine $(7.00 \mathrm{~g}, 18.33 \mathrm{mmol})$ was treated the same way at $100^{\circ} \mathrm{C}$. The degassed octylamine solution was rapidly injected into the trioctylamine solution at $300^{\circ} \mathrm{C}$. Immediately after the injection, the reaction vessel was moved to a $225^{\circ} \mathrm{C}$ prewarmed bath and remained there for 30 minutes under vigorous magnetic stirring. After the reaction was stopped by removing the heating source, the particles were allowed to cool to room temperature. They were dissolved in anhydrous toluene, precipitated by the addition of dry methanol, centrifuged, and again dissolved in anhydrous toluene. This washing step was repeated three times. The stabilized particles were stored under Ar-atmosphere in anhydrous toluene. Nanoparticle sizes were determined by DLS and TEM measurements. The stabilized NPs (NP1) stay soluble for several months, indicating that no agglomeration takes place. IR (KBr-pellet) $v\left(\mathrm{~cm}^{-1}\right) 3450(-\mathrm{OH}), 2926$ $\left(-\mathrm{CH}_{3},-\mathrm{CH}_{2}-\right), 2857\left(-\mathrm{CH}_{3},-\mathrm{CH}_{2}-\right), 1623\left(-\mathrm{NH}_{2}\right)$, $1464\left(-\mathrm{CH}_{3},-\mathrm{CH}_{2}-\right)$.

\subsubsection{Ligand exchange of NP1 leading to NP3a-NP3f}

Surface modification reactions were performed according to the general protocol for ligand exchange reactions of Boal et al. $[35,36]$. All reaction steps were performed under Ar-atmosphere. $50 \mathrm{mg}$ stabilized NPs (NP1) were dissolved in $30 \mathrm{~mL}$ of a 1:1 mixture of $\mathrm{CHCl}_{3}$ and toluene. A second mixture was prepared consisting of $250 \mathrm{mg}$ of diol-ligand $\mathbf{1 a}-\mathbf{f}$ in a 1:1-mixture of chloroform and toluene. If the solubility of the ligand in this mixture was too poor-which occurred using ligands $\mathbf{1 a}, \mathbf{d}, \mathbf{e}-$ the smallest amount of anhydrous isopropanol was added to dissolve the ligand. The ligand solution was added to the nanoparticle solution via a syringe and the reaction mixture was heated up to $50^{\circ} \mathrm{C}$ under vigorous stirring for 2 days. After $\sim 48$ hours, the exchange reaction was finished, resulting in surface modified nanoparticles NP3a-f. The particles were purified by repeated precipitation with dry methanol, centrifugation, and resuspension in anhydrous toluene. Ligand exchange was monitored by FTIR measurements, analyzing the dried modified nanoparticles as $\mathrm{KBr}$-pellets.

NP3a: IR (KBr-pellet) $v\left(\mathrm{~cm}^{-1}\right) 3450(-\mathrm{OH}), 2928$ $\left(-\mathrm{CH}_{3},-\mathrm{CH}_{2}-\right), 2856\left(-\mathrm{CH}_{3},-\mathrm{CH}_{2}-\right), 1702(\mathrm{O}=\mathrm{C}-\mathrm{NH}-$ $\mathrm{C}=\mathrm{O}$, six membered ring), $1450\left(-\mathrm{CH}_{3},-\mathrm{CH}_{2}-\right), 1300$ $(-\mathrm{OH})$. NP3b: IR (KBr-pellet) $v\left(\mathrm{~cm}^{-1}\right) 3420(-\mathrm{OH}), 2920$ $\left(-\mathrm{CH}_{3},-\mathrm{CH}_{2}-\right), 2848\left(-\mathrm{CH}_{3},-\mathrm{CH}_{2}-\right), 2094\left(-\mathrm{N}_{3}\right), 1450$ $\left(-\mathrm{CH}_{3},-\mathrm{CH}_{2}-\right)$. NP3c: IR (KBr-pellet) $v\left(\mathrm{~cm}^{-1}\right) 3420$ $(-\mathrm{OH}), 2924\left(-\mathrm{CH}_{3},-\mathrm{CH}_{2}-\right), 2857\left(-\mathrm{CH}_{3},-\mathrm{CH}_{2}-\right)$, $1469\left(-\mathrm{CH}_{3},-\mathrm{CH}_{2}-\right), 775\left(-\mathrm{CH}_{2}-\mathrm{Br}\right)$. NP3d: IR ( $\mathrm{KBr}-$

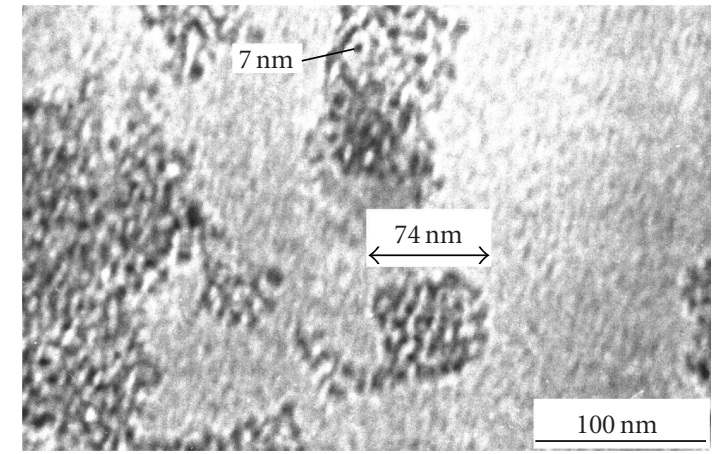

(a)

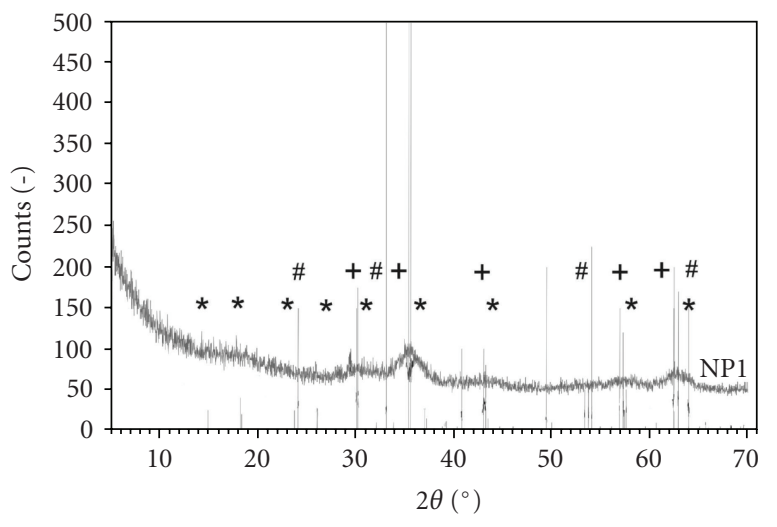

* $\mathrm{Fe}_{2} \mathrm{O}_{3}$ (maghemite-C)

\# $\mathrm{Fe}_{2} \mathrm{O}_{3}$ (hematite)

$+\mathrm{FeFe}_{2} \mathrm{O}_{4}$ (magnetite)

(b)

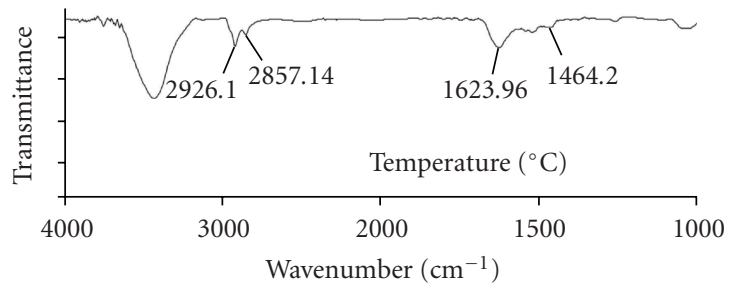

(c)

FIGURE 2: Data for the octylamine-covered nanoparticles NP1 (a) TEM micrograph, (b) XRD of NP1, (c) FT-IR of NP1.

pellet) $v\left(\mathrm{~cm}^{-1}\right) 3433(-\mathrm{OH}), 2956\left(-\mathrm{CH}_{3},-\mathrm{CH}_{2}-\right), 2916$ $\left(-\mathrm{CH}_{3},-\mathrm{CH}_{2}-\right), 2857\left(-\mathrm{CH}_{3},-\mathrm{CH}_{2}-\right), 1450\left(-\mathrm{CH}_{3}\right.$, $\left.-\mathrm{CH}_{2}-\right), 1373\left(-\mathrm{SO}_{2}-\mathrm{NH}-\right), 1150\left(-\mathrm{SO}_{2}-\right)$. NP3e: IR $(\mathrm{KBr}-$ pellet $) v\left(\mathrm{~cm}^{-1}\right) 3420(-\mathrm{OH}), 2951\left(-\mathrm{CH}_{3},-\mathrm{CH}_{2}-\right)$, $2917\left(-\mathrm{CH}_{3},-\mathrm{CH}_{2}-\right), 1628\left(\mathrm{O}=\mathrm{C}-\mathrm{NR}_{2}\right), 1520(\mathrm{O}=\mathrm{C}-$ $\left.\mathrm{NR}_{2}\right), 1450\left(-\mathrm{CH}_{3},-\mathrm{CH}_{2}-\right)$. NP3f: IR (KBr-pellet) $v$ $\left(\mathrm{cm}^{-1}\right) 3431(-\mathrm{OH}), 2920\left(-\mathrm{CH}_{3},-\mathrm{CH}_{2}-\right), 2848\left(-\mathrm{CH}_{3}\right.$, $\left.-\mathrm{CH}_{2}-\right), 1740$ (-COOR), $1456(-\mathrm{N}-\mathrm{O}-), 1260(-\mathrm{OH})$, 1030 (2 signals for esters).

\section{RESULTS AND DISCUSSION}

The basic strategy for the surface modification of the iron oxide nanoparticles with various organic ligands is 


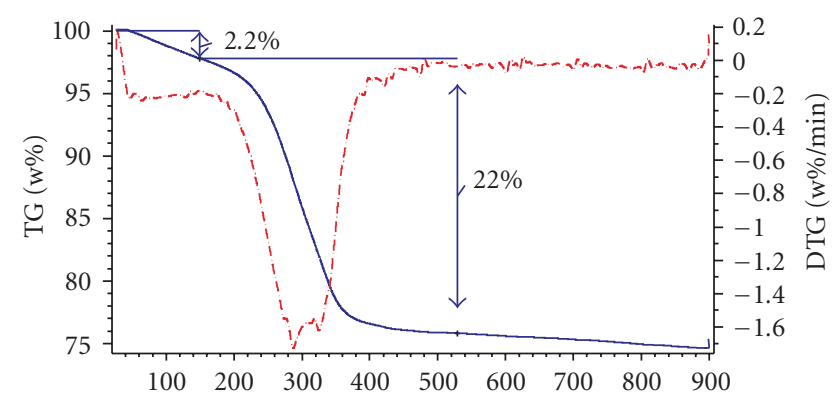

(a)

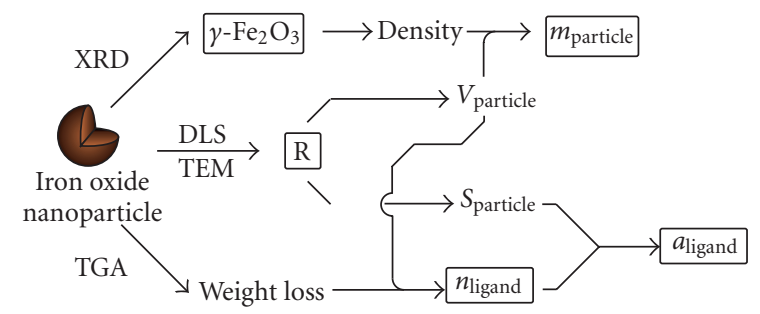

(b)

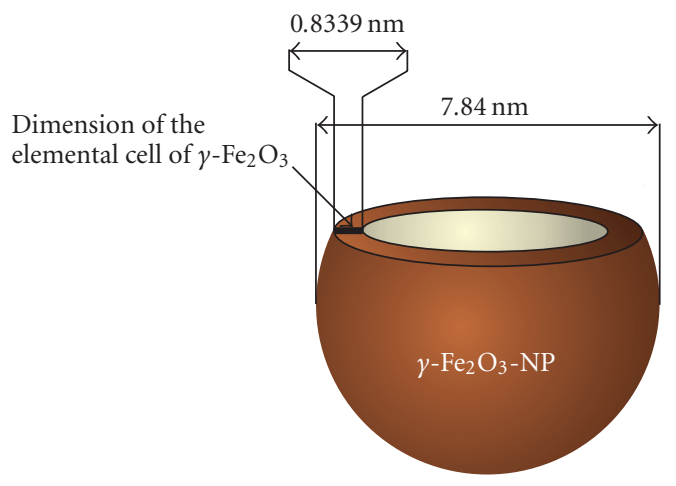

(c)

FIGURE 3: (a) TGA-graph of NP1, (b) schematic flow scheme for the calculation of the theoretical coverage of NP1 with $n$-octylamine as ligand, (c) geometries of shells and shell thicknesses.

shown in Figure 1. Starting from octylamine-covered $\mathrm{Fe}_{2} \mathrm{O}_{3}$ nanoparticles, a direct ligand exchange reaction with substituted 1,2-diols in organic solvents takes place, using the 1,2-diol-moiety as attachment site for the NP-binding. Critical factors, such as the kinetics of ligand exchange, the quantification of surface coverage are described. Basically, four different types of ligands are described: (a) the supramolecular ligands 1a and 1e, (b) ligands bearing the fluorescent label $\mathbf{1 d}$, (c) the azido- and bromine ligands $\mathbf{1 b}$ and $\mathbf{1 c}$, as well as (d) the polymerization initiator $\mathbf{1 f}$.

\subsection{Preparation of 1,2-diol-ligands $1 a-1 f$}

The functionalization of $\gamma$ - $\mathrm{Fe}_{2} \mathrm{O}_{3}$ nanoparticles with different targeting ligands asks for the creation of an effective nanoparticle binding site on the corresponding ligand. Therefore, the synthesis of 1,2-diols (1a-1f) (see Scheme 1) was planned and prepared via a nonstereoselective Sharpless dihydroxylation [38]. The reaction
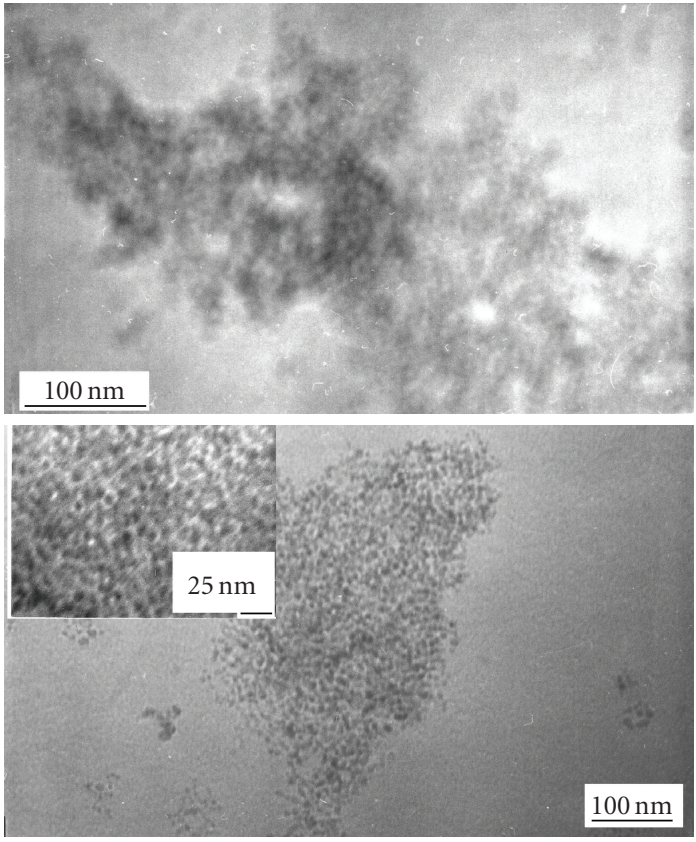

(a)

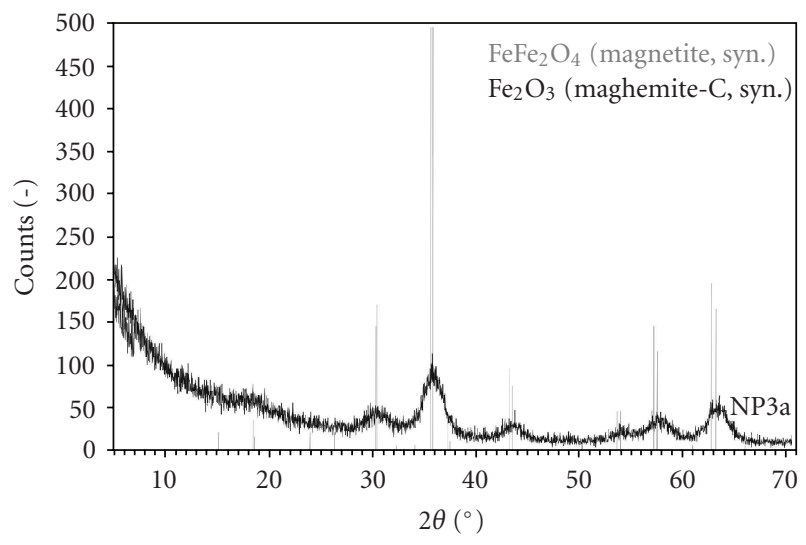

(b)

FIgURE 4: (a) TEM micrographs of NP3a and NP3c, (b) XRD spectrum of NP3a.

was effected by the addition of catalytic amounts of $\mathrm{OsO}_{4}$ to a mixture of $\mathrm{N}$-methyl-morpholine- $\mathrm{N}$-oxide (NMO) and the corresponding (terminal) alkenes 2a-2f in $\mathrm{CH}_{2} \mathrm{Cl}_{2}$. Using this methodology, the ligands $\mathbf{1 a}-\mathbf{1 f}$ were prepared in $85-98 \%$ yield. ${ }^{1} \mathrm{H}-\mathrm{NMR}$ spectra and ${ }^{13} \mathrm{C}$-NMR-spectra are indicative of the high purity and chemical integrity of the prepared samples.

\subsection{Preparation of iron oxide nanoparticles}

Iron oxide nanoparticles were prepared by use of the thermal decomposition of iron cupferron complex in octylamine and trioctylamine (see Scheme 2) at elevated temperatures, as described by Alivisatos [35] and Boal et al. [36], yielding NP1 $(r=3.6-4.2 \mathrm{~nm}$, as determined by DLSmeasurements) with an octylamine shell around the iron 


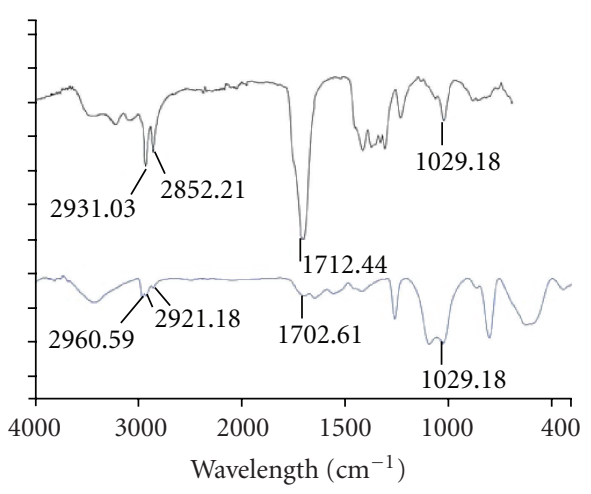

(a)

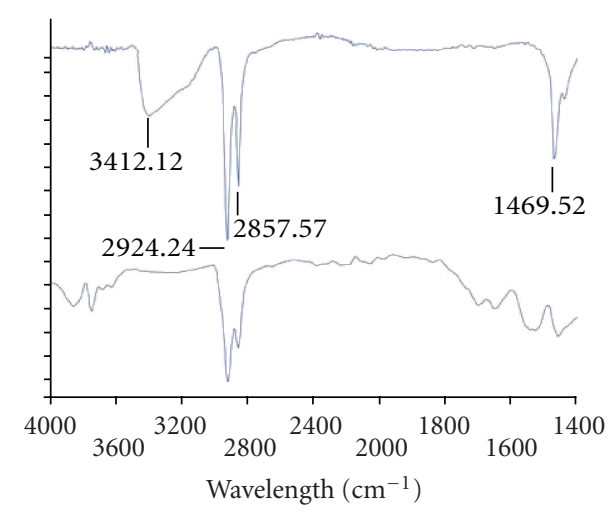

(c)

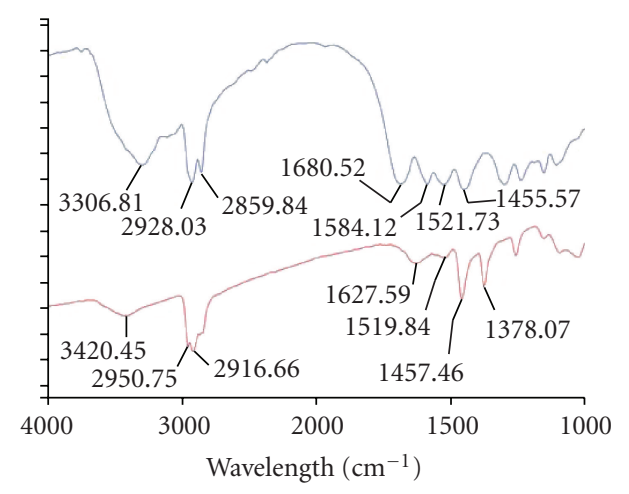

(e)

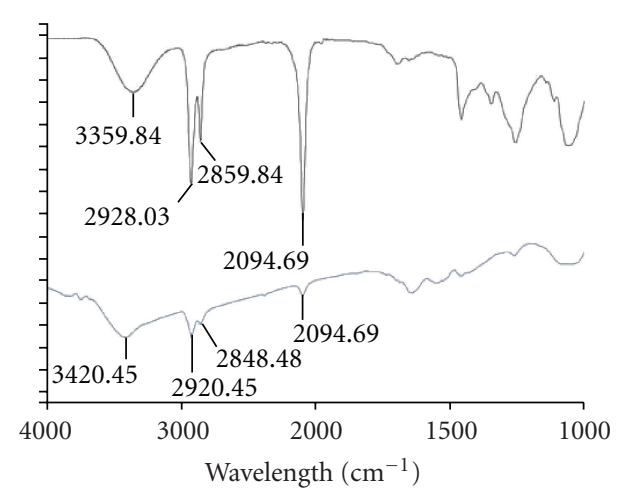

(b)

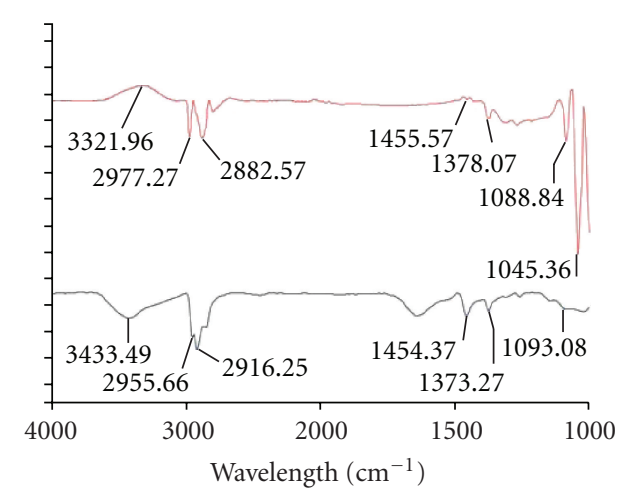

(d)

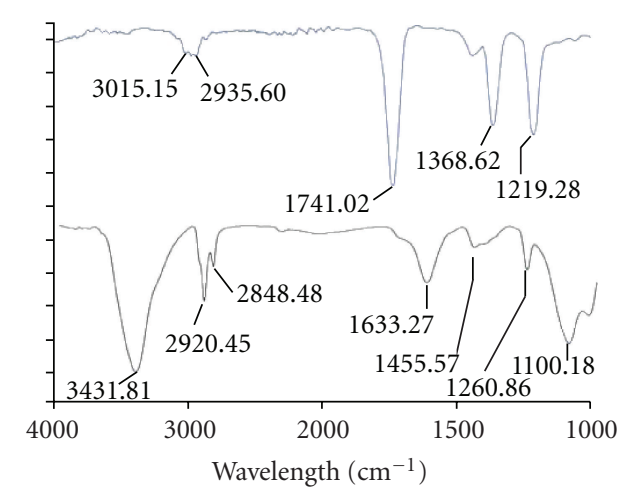

(f)

FIGURE 5: IR spectra of NP's 3a-3f. In each spectrum the upper traces are those of the free ligand, the lower traces those of the corresponding NP-bound ligand. (a) NP3a, (b) NP3b, (c) NP3c, (d) NP3d, (e) NP3e, (f) NP3f.

oxide nanoparticles. The stabilized nanoparticles are soluble for several month, indicating the absence of agglomeration effects.

The nanoparticles NP1 were characterized by UV-VIS and fluorescence-spectroscopy (see supplementary available online at doi:10.1155/2008/383020) as well as via TEM, XRD, and IR-spectroscopy (see Figure 2).

TEM measurements (see Figure 2(a)) were performed to prove the size of the synthesized nanoparticles and to determine the shape of the NPs. According to these measurements, $\gamma-\mathrm{Fe}_{2} \mathrm{O}_{3}$ nanoparticles crystallize in a spherical shape with a diameter of $6-15 \mathrm{~nm}$ which is in good accordance with
DLS results. The determination of the lattice structure of the synthesized nanoparticles was accomplished by powder XRD measurements (see Figure 2(b)). Comparing the resulting reflexes to the patterns of both possible structures revealed that the synthesized nanoparticles crystallize in the $\gamma-\mathrm{Fe}_{2} \mathrm{O}_{3}$ structure. Due to the small size of the nanoparticle in comparison to the bulk material, the reflexes are not as sharp but the angle- $2 \Theta$-values fit to the bulk pattern. FTIR spectroscopy was used to determine the chemical nature of the surface bound ligands, for example, octylamine (see Figure 2(c)). The nanoparticle spectrum (bottom) is showing all peaks at the characteristic frequencies, such 
as $2926 \mathrm{~cm}^{-1}, 2857 \mathrm{~cm}^{-1}(-\mathrm{CH})$, and $1623 \mathrm{~cm}^{-1}\left(-\mathrm{NH}_{2}\right)$, but with a slight line broadening and less intensity. This is in good agreement with literature [36], showing the same phenomenon.

An important parameter concerns the surface coverage of the nanoparticles with the organic ligand (octylamine).

In order to generate a value of significance, both a theoretical calculation and an experimental determination via TGA analysis were performed (see Figures 3(a) and $3(\mathrm{~b}))$. According to the literature [36], $\gamma-\mathrm{Fe}_{2} \mathrm{O}_{3}$ crystallizes in a cubic closed-packed structure. In this sphere, each atom has 6 neighbors in plane and 3 in each plane above and below, leading to a sum of 12 neighbor atoms. Referring to DLS measurements, NP1 has an average radius of $3.92 \mathrm{~nm}$, leading to a volume of the particle of $V_{\text {particle }}=252.32 \mathrm{~nm}^{3}$ and a particle surface of $S_{\text {particle }}=193.10 \mathrm{~nm}^{2}$. Considering the density of $\gamma-\mathrm{Fe}_{2} \mathrm{O}_{3}\left(\rho_{\mathrm{Fe}_{2} \mathrm{O}_{3}}=4.9 \mathrm{~g} / \mathrm{cm}^{3}\right)$, the theoretical mass of one particle $m_{\text {particle }}=1.24 \cdot 10^{-18} \mathrm{~g}$. Taking the surface of one particle $\left(S_{\text {particle }}\right)$ and the binding area of one ligand ( $\left.A_{\text {octylamine }}\right)$ on the nanoparticle surface into account, the amount of surface bound ligands ( $n_{\text {octylamine }}$ ) can be calculated. The binding area of one ligand is assumed as quadratic, therefore, $A_{\text {octylamine }}=\left(a_{\text {octylamine }}\right)^{2}$, where $a_{\text {octylamine }}$ is the side length of the quadratic binding area of one ligand. Using the molecular weight of the surface bound ligand $\left(M_{\text {octylamine }}=129.3 \mathrm{~g} / \mathrm{mol}\right)$, it is now possible to determine the theoretical mass fraction of the surface bound ligands with respect to the total mass of the nanoparticle. Furthermore, paying attention to the molar mass of $\gamma-\mathrm{Fe}_{2} \mathrm{O}_{3}$ $\left(M_{\mathrm{Fe}_{2} \mathrm{O}_{3}}=159.7 \mathrm{~g} / \mathrm{mol}\right)$ and to the length of the elemental cell of $\gamma-\mathrm{Fe}_{2} \mathrm{O}_{3}\left(a_{\mathrm{Fe}_{2} \mathrm{O}_{3}}=0.8339 \mathrm{~nm}\right)$, it is possible to determine the number of $\gamma-\mathrm{Fe}_{2} \mathrm{O}_{3}$-units per nanoparticle $\left(n_{\mathrm{Fe}_{2} \mathrm{O}_{3}}\right)$ and in the outer shell of the nanoparticle $\left(n_{\text {outer } \mathrm{Fe}_{2} \mathrm{O}_{3}}\right)$.

TGA (thermogravimetric analysis) measurements of NP1 were performed to estimate the amount of surface bound ligands. The mass loss of $22.02 \mathrm{w} \%$ indicates that the total mass of a nanoparticle NP1 is composed of $78 \mathrm{w} \%$ iron oxide core and $\mathbf{2 2} \mathbf{w} \%$ organic stabilizing ligand, thus being in excellent accordance to the calculated value. Therefore, TGA was assumed to represent an excellent tool for the characterization of the amount of surface bound ligand.

\subsection{Ligand exchange with 1,2-diols}

Using the general protocol for ligand exchange reactions according to Boal et al. [36], stabilized NP1 are treated with a 5-fold excess of diol-ligand $\mathbf{1 a}-\mathbf{f}$ in a $1: 1$-mixture of $\mathrm{CHCl}_{3}$ and toluene at $50^{\circ} \mathrm{C}$. The reaction finished after 48 hours resulting in surface modified nanoparticles NP3a-f. The particle size was determined by DLS measurements showing no change in particle diameter.

A first hint at a successful ligand exchange was provided by solubility experiments. Thus the solubility of NP3af was rather different as compared to the nonmodified nanoparticle (NP1a-d). Whereas NP3a, c, f were completely soluble in common organic nonpolar aprotic solvents, such as $\mathrm{CHCl}_{3}$ and toluene, NP3a, $\mathbf{d}$, e were only poorly soluble in any of these solvents, presumably due to self aggregation

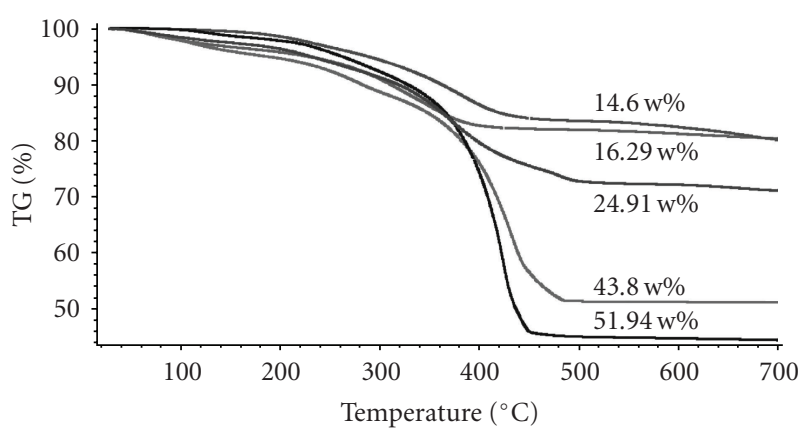

FIgURE 6: TGA curves for the surface-modified nanoparticles NP3a-NP3d and NP3f. (data: NP3a (14.60\%), NP3b (43.80\%), NP3c (24.91\%), NP3d (16.29\%), and NP3f (51.94\%).

phenomena of the respective multiple hydrogen bonding interaction, now present at their surface due to the ligand exchange reaction. Even ultrasonic irradiation was not able to improve their solubility. NP3a were soluble in dipolar aprotic solvents such as in DMF or THF. This behavior is also visible in TEM measurements, where the formation of aggregates of nanoparticles NP3a is clearly visible (see Figure 4(a)) in comparison to the noninteracting NP3c. XRD measurement still indicates the presence of $\gamma-\mathrm{Fe}_{2} \mathrm{O}_{3}$ after the exchange reaction (see Figure 4(b)).

In order to fully characterize the surface bound ligands on NP3a-f, FTIR measurements were performed. Figures 5(a)-5(f) show the IR spectra of all synthesized nanoparticles, in each case the upper spectrum shows the unbound ligand, the lower one of the functionalized NPs. Since the binding site of the ligand on the nanoparticle is the electron donating diol group, an $\mathrm{OH}$-signal is always present at $\sim 3400 \mathrm{~cm}^{-1}$. Furthermore, characteristic peaks are always present, thus proving the presence of the ligands on the NP-surface. NP3a show a characteristic carbonyl signal at $1702 \mathrm{~cm}^{-1}, \mathbf{N P 3 b}$ show a significant azide band at $2094 \mathrm{~cm}^{-1}$. Furthermore, NP3c show a typical band at $1470 \mathrm{~cm}^{-1}$ and in NP3d the band at $1373 \mathrm{~cm}^{-1}$ for the sulfonamide moiety is clearly visible. NP3eshow a significant band at $1628 \mathrm{~cm}^{-1}$ for the amide and in NP3f a signal at $1456 \mathrm{~cm}^{-1}$ is indicative for the nitroxide moiety.

Again, as already demonstrated before, TGA (see Figure 6) and DLS results were used for the determination of the number of surface bound ligands, the number of iron centers on the surface, and the ligand binding area. The following nanoparticles were analyzed: NP3a-d and NP3f. The results are compiled in the following table (Table 1). Comparison of the weight loss gained by TGA measurements and calculations based on the hydrodynamic radius gained by DLS shows an excellent match, thus proving the complete ligand exchange.

\subsection{Kinetics of the ligand exchange reaction}

This is an important point concerning the follow-up of the ligand exchange kinetics during the incubation of the octylamine-covered nanoparticles with the 1,2-diol-ligands. 


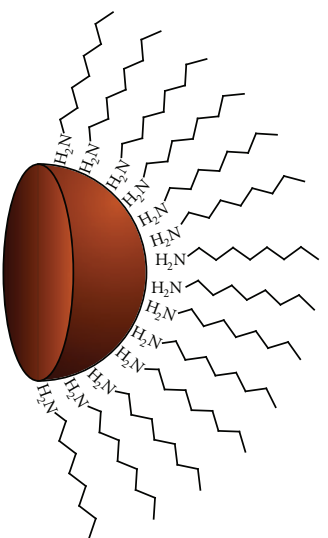

$t_{0}$

NP1
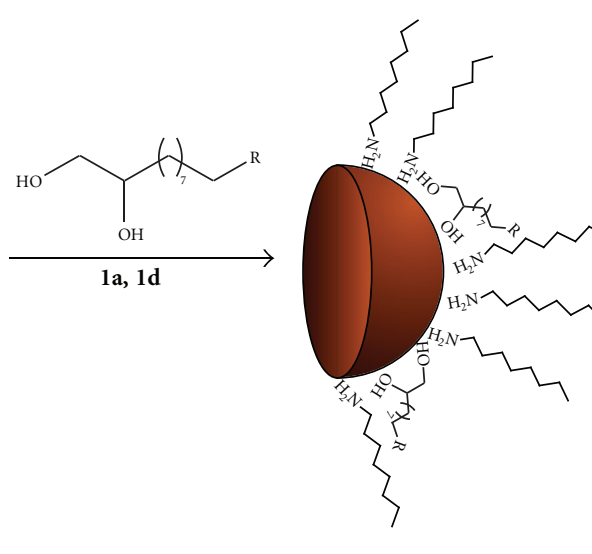

$t_{1}$

(a)

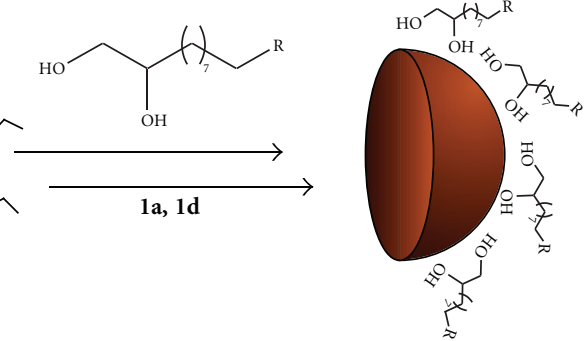

$t_{n}$

NP3a,d

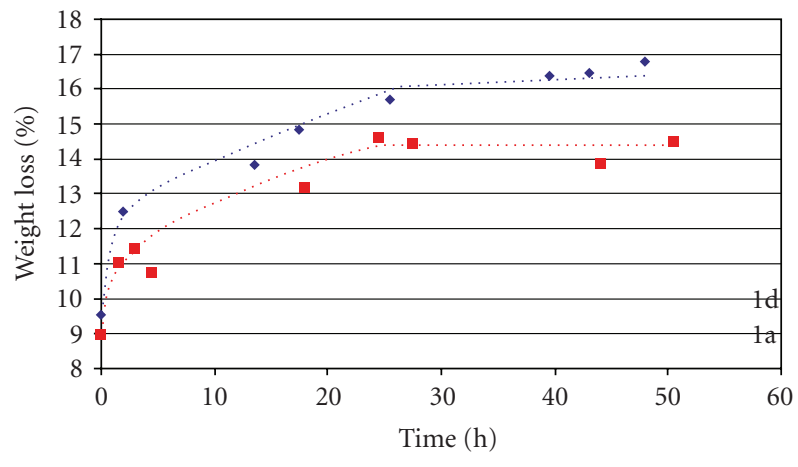

- Dansyl-ligand

- Barbituric acid-ligand

(b)

FIGURE 7: Ligand exchange experiments monitored via TGA. (a) Scheme for the exchange of NP1 with the ligands 1a and 1d, (b) plot of the TGA mass loss versus time.

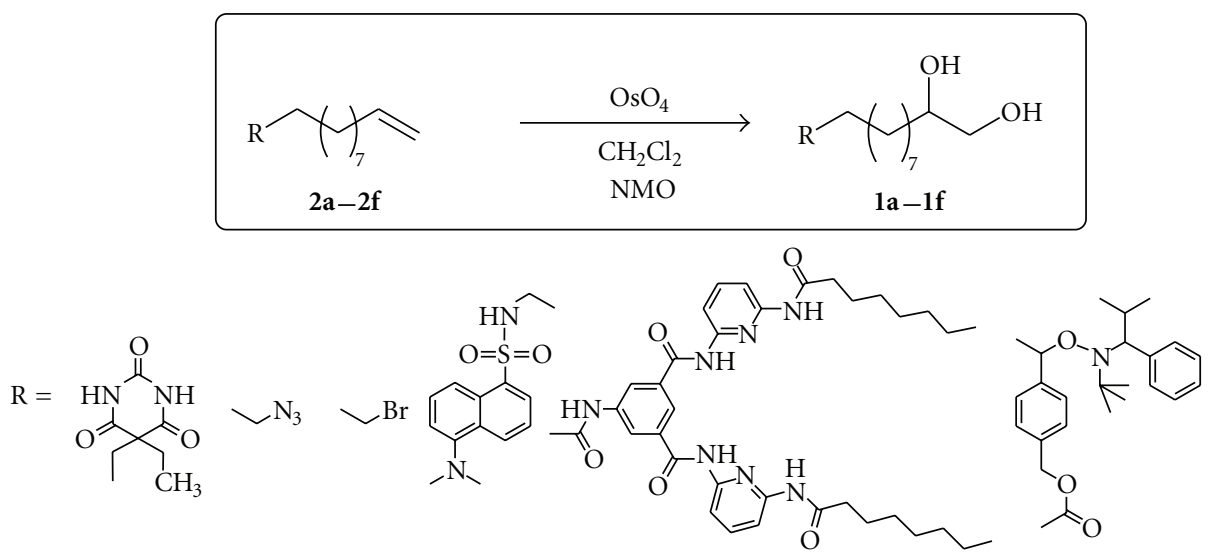
(a)
(b)
(c)
(d)
(e)
(f)

Scheme 1: Synthesis of the 1,2-diol-ligands $\mathbf{1 a}-\mathbf{1 f}$ via dihydroxylation of the corresponding terminal alkenes $\mathbf{2 a - 2 f}$.

As described by Boal et al. [36]. a time of 48 hours is required for all diol-ligands to effect the efficient exchange reaction, replacing the intitial octylamine ligand by the much harder alcohol. However, ligands bearing monovalent 
TABLE 1: TGA data and calculation parameters for NP3a-NP3d, NP3f.

\begin{tabular}{|c|c|c|c|c|c|}
\hline Parameter & NP3a & NP3b & NP3c & NP3d & NP3f \\
\hline$r_{\text {particle }}$ & $3.92 \mathrm{~nm}$ & $3.59 \mathrm{~nm}$ & $5.15 \mathrm{~nm}$ & $3.92 \mathrm{~nm}$ & $8.61 \mathrm{~nm}$ \\
\hline$V_{\text {particle }}$ & $252.32 \mathrm{~nm}^{3}$ & $193.81 \mathrm{~nm}^{3}$ & $572.15 \mathrm{~nm}^{3}$ & 252. $\mathrm{nm}^{3}$ & $2668.95 \mathrm{~nm}^{3}$ \\
\hline$S_{\text {particle }}$ & $193.10 \mathrm{~nm}^{2}$ & $161.96 \mathrm{~nm}^{2}$ & $333.29 \mathrm{~nm}^{2}$ & $193.10 \mathrm{~nm}^{2}$ & $930.49 \mathrm{~nm}^{2}$ \\
\hline$m_{\text {particle }}$ & $1.24 \cdot 10^{-18} \mathrm{~g}$ & $9.50 \cdot 10^{-19} \mathrm{~g}$ & $2.80 \cdot 10^{-18} \mathrm{~g}$ & $1.24 \cdot 10^{-18} \mathrm{~g}$ & $1.31 \cdot 10^{-17} \mathrm{~g}$ \\
\hline$a_{\text {ligand }}$ & $0.75 \mathrm{~nm}$ & $0.29 \mathrm{~nm}$ & $0.40 \mathrm{~nm}$ & $0.75 \mathrm{~nm}$ & $0.26 \mathrm{~nm}$ \\
\hline$n_{\text {ligand }}$ & 343 & 1926 & 2083 & 343 & 14888 \\
\hline$n_{\text {ligand TGA }}$ & 372 & 1946 & 2098 & 332 & 15336 \\
\hline$n_{\text {iron centers }}$ & 1592 & 1307 & 2899 & 1592 & 8662 \\
\hline$n_{\text {outer } \mathrm{Fe}_{2} \mathrm{O}_{3}}$ & 2387 & 1961 & 4349 & 2387 & 12993 \\
\hline$n_{\mathrm{Fe}_{2} \mathrm{O}_{3}}$ & 4662 & 3581 & 10572 & 4662 & 49317 \\
\hline CALC $_{\text {mass loss }}$ & $13.64 \mathrm{w} \%$ & $43.54 \mathrm{w} \%$ & $24.78 \mathrm{w} \%$ & $16.76 \mathrm{w} \%$ & 51.20 w\% \\
\hline $\mathrm{TGA}_{\text {mass loss }}$ & $14.60 \mathrm{w} \%$ & $43.80 \mathrm{w} \%$ & $24.91 \mathrm{w} \%$ & $16.29 \mathrm{w} \%$ & $51.94 \mathrm{w} \%$ \\
\hline
\end{tabular}

hydroxyl moieties are not stable over a long term, leading to irreversible aggregation of the nanoparticles after the eventual loss of the covering ligand.

We therefore have studied the kinetics of the ligand exchange reaction of NP1 with ligands $\mathbf{1 a}$ and $\mathbf{1 d}$ (see Figure 7(a)), enabling to follow the ligand exchange via TGA due to the significant increase in weight when compared to the octylamine ligand in NP1. The nanoparticles NP1 were treated under standard ligand exchange conditions with the corresponding diol-ligand (1a and 1d), respectively. Samples of $\sim 5 \mathrm{mg}$ were taken at different time points $\left(t_{1} \cdots t_{n}\right)$, purified by repeated precipitation, and analyzed thermogravimetrically. The weight loss was plotted versus time resulting in the results in Figure 7(b), indicating a saturation law. The final theoretical mass loss was calculated and compared to the values gained by TGA measurements. The calculated values of $16.76 \mathrm{w} \%$ of ligand $1 \mathbf{d}$ on NP3d are in excellent accordance with the measured value of $16.29 \mathrm{w} \%$ (NP3d) elicited by TGA. In case of NP3a, the theoretically calculated mass loss of $13.64 \mathrm{w} \%$ fits well the measured value of $14,60 \mathrm{w} \%$ determined by TGA. In comparision to the results obtained by parallel FTIR measurements (data not shown), TGA results indicate a complete exchange of octylamine after 24 hours whereas IR results indicate a reaction time of 48 hours.

Therefore, it can be concluded that a complete ligand exchange reaction can be effected within one day of reaction time using a nonpolar reaction medium.

\section{CONCLUSION}

In summary, we have developed an easy access to the surface modification of $\gamma-\mathrm{Fe}_{2} \mathrm{O}_{3}$ nanoparticles via exchange reaction with 1,2-diols. The generation of the corresponding ligands is simple, since the 1,2-dihydroxylation reaction can be performed in the presence of a multitude of functional groups, as demonstrated with the ligands 1a-1f. Clearly, the method offers the possibility to engineer superparamagnetic iron oxide nanoparticles with a large variety of functional organic ligands, being bound stable to the nanoparticle surface.

\section{ACKNOWLEDGMENTS}

The authors thank the FWF, Project no. 18740B03 for financial support. Dietrich Gloger is thanked for the synthesis of the nitroxide precursor $2 \mathrm{f}$ [39].

\section{REFERENCES}

[1] C. Scherer and A. M. Figueiredo Neto, "Ferrofluids: properties and applications," Brazilian Journal of Physics, vol. 35, no. 3 A, pp. 718-727, 2005.

[2] T. P. Raming, A. J. A. Winnubst, C. M. van Kats, and A. P. Philipse, "The synthesis and magnetic properties of nanosized hematite $\left(\alpha-\mathrm{Fe}_{2} \mathrm{O}_{3}\right)$ particles," Journal of Colloid and Interface Science, vol. 249, no. 2, pp. 346-350, 2002.

[3] A. K. Gupta and S. Wells, "Surface-modified superparamagnetic nanoparticles for drug delivery: preparation, characterization, and cytotoxicity studies ," IEEE Transactions on Nanobioscience, vol. 3, no. 1, pp. 66-73, 2004.

[4] T. Neuberger, B. Schöpf, H. Hofmann, M. Hofmann, and B. von Rechenberg, "Superparamagnetic nanoparticles for biomedical applications: possibilities and limitations of a new drug delivery system," Journal of Magnetism and Magnetic Materials, vol. 293, no. 1, pp. 483-496, 2005.

[5] S. Mornet, S. Vasseur, F. Grasset, et al., "Magnetic nanoparticle design for medical applications," Progress in Solid State Chemistry, vol. 34, no. 2-4, pp. 237-247, 2006.

[6] A. K. Gupta and M. Gupta, "Synthesis and surface engineering of iron oxide nanoparticles for biomedical applications," Biomaterials, vol. 26, no. 18, pp. 3995-4021, 2005.

[7] D. C. F. Chan, D. B. Kirpotin, and P. A. Bunn Jr., "Synthesis and evaluation of colloidal magnetic iron oxides for the site-specific radiofrequency-induced hyperthermia of cancer," Journal of Magnetism and Magnetic Materials, vol. 122, no. 13, pp. 374-378, 1993.

[8] A. Ito, M. Shinkai, H. Honda, and T. Kobayashi, "Heatinducible $T N F-\alpha$ gene therapy combined with hyperthermia using magnetic nanoparticles as a novel tumor-targeted therapy," Cancer Gene Therapy, vol. 8, no. 9, pp. 649-654, 2001. 
[9] J. M. Kinsella and A. Ivanisevic, "Enzymatic clipping of DNA wires coated with magnetic nanoparticles," Journal of the American Chemical Society, vol. 127, no. 10, pp. 3276-3277, 2005.

[10] C.-L. Chiang, C.-S. Sung, T.-F. Wu, C.-Y. Chen, and C.Y. Hsu, "Application of superparamagnetic nanoparticles in purification of plasmid DNA from bacterial cells," Journal of Chromatography B, vol. 822, no. 1-2, pp. 54-60, 2005.

[11] S. W. Kamau, P. O. Hassa, B. Steitz, et al., "Enhancement of the efficiency of non-viral gene delivery by application of pulsed magnetic field," Nucleic Acids Research, vol. 34, no. 5, p. e40, 2006.

[12] S. M. Gravaimo, R. Dumas, K. Liu, and T. E. Patten, "Methods for the surface functionalization of $\gamma-\mathrm{Fe}_{2} \mathrm{O}_{3}$ nanoparticles with initiators for atom transfer radical polymerization and the formation of core-shell inorganic-polymer structures," Journal of Polymer Science Part A, vol. 43, no. 16, pp. 36753688, 2005.

[13] T. Ninjbadgar, S. Yamamoto, and T. Fukuda, "Synthesis and magnetic properties of the $\gamma-\mathrm{Fe}_{2} \mathrm{O}_{3} /$ poly-(methyl methacrylate)-core/shell nanoparticles," Solid State Sciences, vol. 6, no. 8, pp. 879-885, 2004.

[14] F. Hu, K. G. Neoh, L. Cen, and E.-T. Kang, "Cellular response to magnetic nanoparticles "PEGylated" via surface-initiated atom transfer radical polymerization," Biomacromolecules, vol. 7, no. 3, pp. 809-816, 2006.

[15] I. Koh, X. Wang, B. Varughese, L. Isaacs, S. H. Ehrman, and D. S. English, "Magnetic iron oxide nanoparticles for biorecognition: evaluation of surface coverage and activity," Journal of Physical Chemistry B, vol. 110, no. 4, pp. 1553-1558, 2006.

[16] N. Nitin, L. E. W. LaConte, O. Zurkiya, X. Hu, and G. Bao, "Functionalization and peptide-based delivery of magnetic nanoparticles as an intracellular MRI contrast agent," Journal of Biological Inorganic Chemistry, vol. 9, no. 6, pp. 706-712, 2004.

[17] A. Dyal, K. Loos, M. Noto, et al., "Activity of Candida rugosa lipase immobilized on $\gamma$ - $\mathrm{Fe}_{2} \mathrm{O}_{3}$ magnetic nanoparticles," Journal of the American Chemical Society, vol. 125, no. 7, pp. 1684$1685,2003$.

[18] Z. Guo and Y. Sun, "Characteristics of immobilized lipase on hydrophobic superparamagnetic microspheres to catalyze esterification," Biotechnology Progress, vol. 20, no. 2, pp. 500506, 2004.

[19] S.-H. Huang, M.-H. Liao, and D.-H. Chen, "Direct binding and characterization of lipase onto magnetic nanoparticles," Biotechnology Progress, vol. 19, no. 3, pp. 1095-1100, 2003.

[20] Y. Lu, Y. Yin, B. T. Mayers, and Y. Xia, "Modifying the surface properties of superparamagnetic iron oxide nanoparticles through a sol-gel approach," Nano Letters, vol. 2, no. 3, pp. 183-186, 2002.

[21] F. Cengelli, D. Maysinger, F. Tschudi-Monnet, et al., "Interaction of functionalized superparamagnetic iron oxide nanoparticles with brain structures," Journal of Pharmacology and Experimental Therapeutics, vol. 318, no. 1, pp. 108-116, 2006.

[22] J. Choi, J. I. Lee, Y. B. Lee, et al., "Immobilization of biomolecules on biotinylated magnetic ferrite nanoparticles," Chemical Physics Letters, vol. 428, no. 1-3, pp. 125-129, 2006.

[23] Z. Ma, Y. Guan, and H. Liu, "Superparamagnetic silica nanoparticles with immobilized metal affinity ligands for protein adsorption," Journal of Magnetism and Magnetic Materials, vol. 301, no. 2, pp. 469-477, 2006.

[24] N. Kohler, C. Sun, J. Wang, and M. Zhang, "Methotrexatemodified superparamagnetic nanoparticles and their intracel- lular uptake into human cancer cells," Langmuir, vol. 21, no. 19, pp. 8858-8864, 2005.

[25] P. S. Haddad, E. L. Duarte, M. S. Baptista, G. F. Goya, C. A. P. Leite, and R. Itri, "Synthesis and characterization of silica-coated magnetic nanoparticles," Progress in Colloid and Polymer Science, vol. 128, pp. 232-238, 2004.

[26] L. Wang, J. Luo, M. M. Maye, et al., "Iron oxide-gold core-shell nanoparticles and thin film assembly," Journal of Materials Chemistry, vol. 15, no. 18, pp. 1821-1832, 2005.

[27] L. M. Rossi, A. D. Quach, and Z. Rosenzweig, "Glucose oxidase-magnetite nanoparticle bioconjugate for glucose sensing," Analytical and Bioanalytical Chemistry, vol. 380, no. 4, pp. 606-613, 2004.

[28] H. M. R. Gardimalla, D. Mandal, P. D. Stevens, M. Yen, and Y. Gao, "Superparamagnetic nanoparticle-supported enzymatic resolution of racemic carboxylates," Chemical Communications, no. 35, pp. 4432-4434, 2005.

[29] S. Giri, B. G. Trewyn, M. P. Stellmaker, and V. S.-Y. Lin, "Stimuli-responsive controlled-release delivery system based on mesoporous silica nanorods capped with magnetic nanoparticles," Angewandte Chemie International Edition, vol. 44, no. 32, pp. 5038-5044, 2005.

[30] R. Tadmor, R. E. Rosensweig, J. Frey, and J. Klein, "Resolving the puzzle of ferrofluid dispersants," Langmuir, vol. 16, no. 24, pp. 9117-9120, 2000.

[31] R. E. Rosensweig, R. Kaiser, and G. Miskolczy, "Viscosity of magnetic fluid in a magnetic field," Journal of Colloid and Interface Science, vol. 29, no. 4, pp. 680-686, 1969.

[32] J. Lu, J. Fan, R. Xu, S. Roy, N. Ali, and Y. Gao, "Synthesis of alkyl sulfonate/alcohol-protected $\gamma-\mathrm{Fe}_{2} \mathrm{O}_{3}$ nanocrystals with narrow size distributions," Journal of Colloid and Interface Science, vol. 258, no. 2, pp. 427-431, 2003.

[33] G. Kataby, A. Ulman, R. Prozorov, and A. Gedanken, "Coating of amorphous iron nanoparticles by long-chain alcohols," Langmuir, vol. 14, no. 7, pp. 1512-1515, 1998.

[34] C. Yee, G. Kataby, A. Ulman, et al., "Self-assembled monolayers of alkanesulfonic and -phosphonic acids on amorphous iron oxide nanoparticles," Langmuir, vol. 15, no. 21, pp. 71117115, 1999.

[35] J. Rockenberger, E. C. Scher, and A. P. Alivisatos, "A new nonhydrolytic single-precursor approach to surfactantcapped nanocrystals of transition metal oxides," Journal of the American Chemical Society, vol. 121, no. 49, pp. 11595-11596, 1999.

[36] A. K. Boal, K. Das, M. Gray, and V. M. Rotello, "Monolayer exchange chemistry of $\gamma$ - $\mathrm{Fe}_{2} \mathrm{O}_{3}$ nanoparticles," Chemistry of Materials, vol. 14, no. 6, pp. 2628-2636, 2002.

[37] W. H. Binder and C. Kluger, "Combining ring-opening metathesis polymerization (ROMP) with sharpless-type "click" reactions: an easy method for the preparation of side chain functionalized poly(oxynorbornenes)," Macromolecules, vol. 37, no. 25, pp. 9321-9330, 2004.

[38] G. A. Crispino, P. T. Ho, and K. B. Sharpless, "Selective perhydroxylation of squalene: taming the arithmetic demon," Science, vol. 259, no. 5091, pp. 64-66, 1993.

[39] W. H. Binder, D. Gloger, H. Weinstabl, G. Allmaier, and E. Pittenauer, "Telechelic poly $(N$-isopropylacrylamides $)$ via nitroxide-mediated controlled polymerization and "click" chemistry: livingness and "grafting-from" methodology," Macromolecules, vol. 40, no. 9, pp. 3097-3107, 2007. 

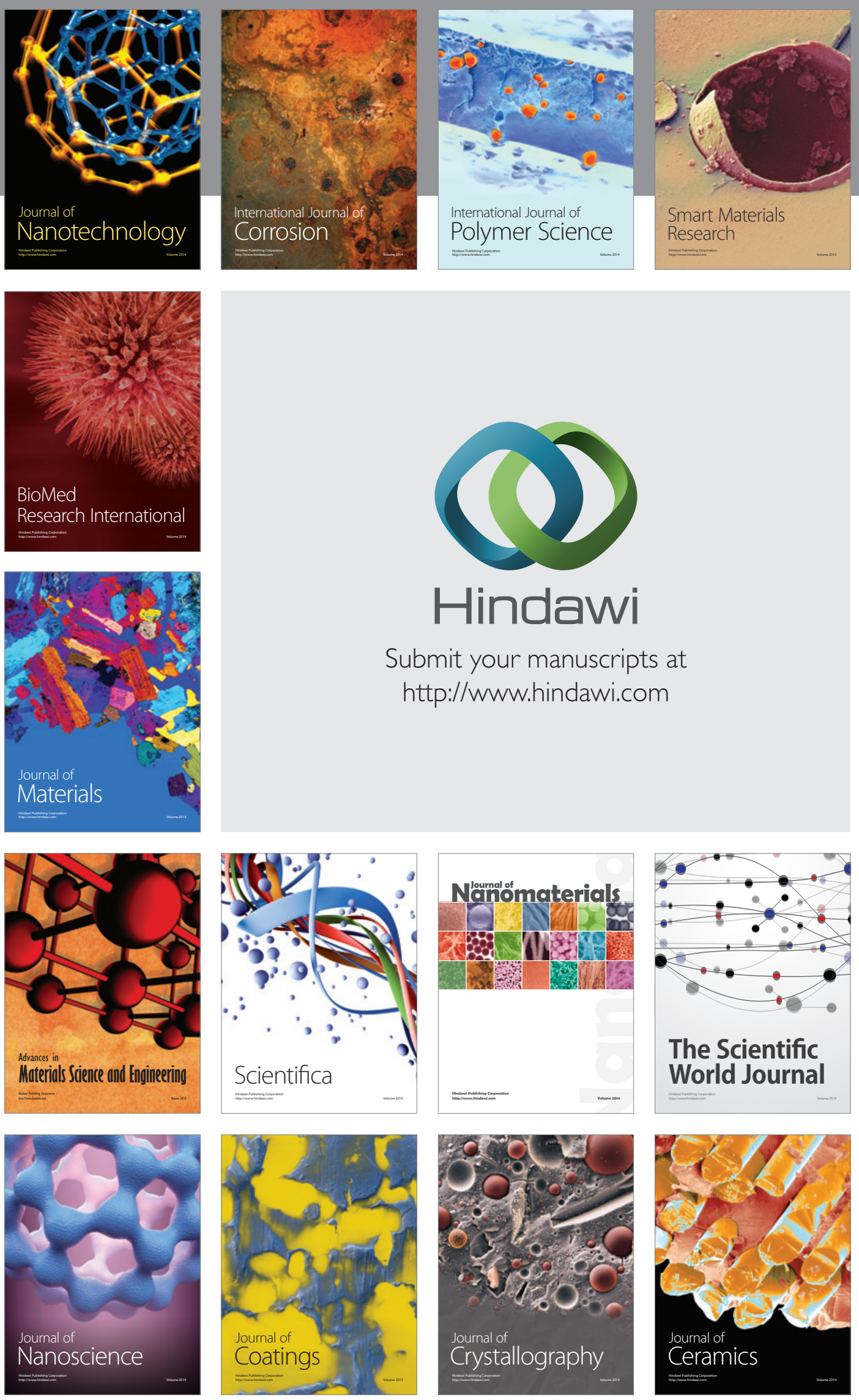

The Scientific World Journal

Submit your manuscripts at

http://www.hindawi.com

\section{World Journal}

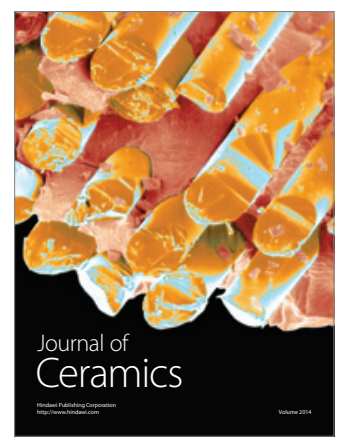

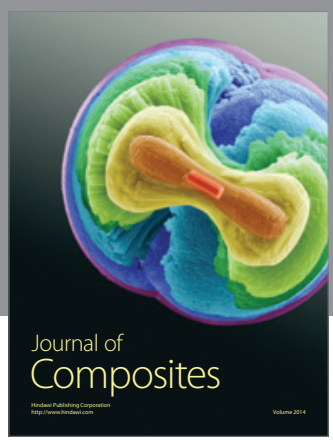
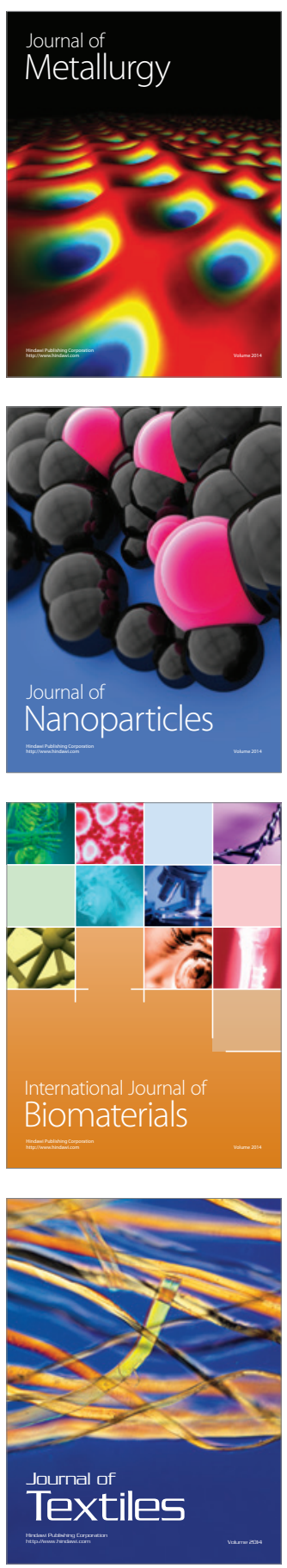